\title{
Square-Wave Voltammetric Determination of Acetylsalicylic Acid in Pharmaceutical Formulations using a Boron-Doped Diamond Electrode without the Need of Previous Alkaline Hydrolysis Step
}

\author{
Elen R. Sartori, Roberta A. Medeiros, Romeu C. Rocha-Filho and Orlando Fatibello-Filho* \\ Departamento de Química, Universidade Federal de São Carlos, CP 676, 13560-970 São Carlos-SP, Brazil
}

\begin{abstract}
Neste trabalho descreve-se a determinação do ácido acetilsalicílico (ASA) em formulações farmacêuticas empregando voltametria de onda quadrada (SWV) e um eletrodo de diamante dopado com boro (BDD). Neste método, ASA é determinado diretamente em solução de $\mathrm{H}_{2} \mathrm{SO}_{4} 0,01 \mathrm{~mol} \mathrm{~L}^{-1}$, sem a necessidade da hidrólise alcalina. Foi obtido um único pico de oxidação no potencial de 1,97 V vs. Ag/AgCl ( $\left.\mathrm{KCl} 3,0 \mathrm{~mol} \mathrm{~L}^{-1}\right)$ com características de uma reação irreversível. A curva analítica obtida é linear na faixa de concentração ASA de $2,50 \times 10^{-6}-1,05 \times 10^{-4} \mathrm{~mol} \mathrm{~L}^{-1}$, com um limite de detecção de $2,0 \mu \mathrm{mol} \mathrm{L}{ }^{-1}$. O desvio padrão relativo foi menor que $1,4 \%$ para uma solução de ASA $45 \mu \mathrm{mol} \mathrm{L}{ }^{-1}(n=10)$. O método proposto foi aplicado com sucesso para a determinação de ASA em várias formulações farmacêuticas e os resultados obtidos foram concordantes com um método oficial da Farmacopéia Britânica, a um nível de confiança de 95\%.
\end{abstract}

In this paper the determination of acetylsalicylic acid (ASA) in pharmaceutical formulations using square-wave voltammetry (SWV) and a boron-doped diamond electrode (BDD) is described. By this proposed method, ASA is directly determined in a $0.01 \mathrm{~mol} \mathrm{~L}^{-1} \mathrm{H}_{2} \mathrm{SO}_{4}$ solution without the need of a previous time-consuming alkaline hydrolysis step. A single oxidation peak at a potential of $1.97 \mathrm{~V} v s . \mathrm{Ag} / \mathrm{AgCl}\left(3.0 \mathrm{~mol} \mathrm{~L}^{-1} \mathrm{KCl}\right)$ with the characteristics of an irreversible reaction was obtained. The obtained analytical curve is linear in the ASA concentration range $2.50 \times 10^{-6}-1.05 \times 10^{-4} \mathrm{~mol} \mathrm{~L}^{-1}$, with a detection limit of $2.0 \mu \mathrm{mol} \mathrm{L} \mathrm{L}^{-1}$. The obtained relative standard deviation was smaller than $1.4 \%$ for a $45 \mu \mathrm{mol} \mathrm{L}^{-1}$ ASA solution $(\mathrm{n}=10)$. The proposed method was applied with success in the determination of ASA in several pharmaceutical formulations; the obtained results were in close agreement, at a 95\% confidence level, with those obtained using an official method of the British Pharmacopoeia.

Keywords: acetylsalicylic acid determination, boron-doped diamond electrode, square-wave voltammetry, pharmaceutical formulations

\section{Introduction}

Acetylsalicylic acid (ASA), shown in Figure 1, more popularly known as aspirin, is one of the oldest medicines that still plays an important role in modern therapeutics. It is widely employed in pharmaceutical formulations for the relief of headaches, fever, muscular pain, and inflammation due to arthritis or injury. It was first synthesized in 1897, by Felix Hoffmann, in the Farbenfabrik Freidrich Bayer laboratories, in Elberfeld, Germany. ${ }^{1,2}$ The high consumption of this substance all over the world ${ }^{3,4}$ indicates the importance of the development of

*e-mail: bello@ufscar.br new analytical methods to assess not only the quality but also the authenticity of the product.

The rate of decomposition of ASA to salicylic acid (SA) and acetic acid (AA) is dependent on solution $\mathrm{pH}$ and temperature. In the $\mathrm{pH}$ range 11-12 ASA is quickly hydrolyzed, in the $\mathrm{pH}$ range 4-8 its hydrolysis rate is slow, and maximum stability is attained at $\mathrm{pH} 2-3 .{ }^{5}$ Commonly, ASA is indirectly determined after its conversion to SA<smiles>CC(=O)Oc1ccccc1C(=O)O</smiles>

Figure 1. Chemical structure of acetylsalicylic acid (ASA). 
and AA by alkaline hydrolysis. According to a British Pharmacopoeia method, ${ }^{6}$ the ASA sample is dissolved in a sodium hydroxide solution and heated under reflux for $10 \mathrm{~min}$; after cooling the solution to ambient temperature, the $\mathrm{NaOH}$ excess is titrated with a $\mathrm{HCl}$ standardized solution. Another reference method for the determination of SA is the spectrophotometric method based on the Trinder reaction, ${ }^{7}$ which involves the formation of a deep blue-violet complex between salicylate and Fe(III). However, this is not an indicated method to determine ASA in samples that have dyes in their formulation, because serious interferences might be expected.

Several other methods for ASA determination in pharmaceuticals formulations, some of them combined with a flow-injection system, were also proposed; for example, the quantitative reflectance spot test, ${ }^{8}$ spectrophotometric, ${ }^{9-11}$ fluorimetric, ${ }^{12}$ and chromatographic ${ }^{13,14}$ methods. The use of HPLC is preferred over other methods because of the possibility of simultaneous determination of ASA and SA. However, this technique involves expensive apparatus and a usually difficult and tedious preparation of the samples.

Electroanalytical methods such as potentiometric and amperometric ones were also developed for the analysis of acetylsalicylic acid in pharmaceuticals formulations. Ferreira et al. ${ }^{15}$ constructed an electrode of the second kind, $\mathrm{Pt}|\mathrm{Hg}| \mathrm{Hg}_{2}$ (salic) ${ }_{2}$ graphite, sensitive to salicylate, for the determination of ASA, after its hydrolysis to salicylate, with a sensitivity of $58.66 \mathrm{mV} \mathrm{decade}^{-1}$ in the ASA concentration range $6.0 \times 10^{-4} \mathrm{~mol} \mathrm{~L}^{-1}$ to $1.0 \times 10^{-1} \mathrm{~mol} \mathrm{~L}^{-1}$ at $\mathrm{pH} 6.0$ and ionic strength of 0.50 3.0 mol L-1, adjusted with $\mathrm{NaClO}_{4}$. Kubota et al. ${ }^{16}$ developed a potentiometric flow-injection system for ASA determination after an on-line hydrolysis of an alcoholic ASA solution; the used tubular potentiometric electrode was based on Aliquat-salicylate as ion-exchanger. This electrode showed a linear response to ASA in the concentration range $4.0 \times 10^{-3} \mathrm{~mol} \mathrm{~L}^{-1}$ to $4.0 \times 10^{-2} \mathrm{~mol} \mathrm{~L}^{-1}$, with an analytical frequency of 28 samples $^{-1}$. Fernandes et $a l .{ }^{17}$ used a batch injection analysis (BIA) system for the potentiometric ASA determination in tablets, with a salicylate ion selective electrode. This system showed a linear response to ASA in the concentration range $7.5 \times 10^{-3} \mathrm{~mol} \mathrm{~L}^{-1}$ to $7.5 \times 10^{-2} \mathrm{~mol} \mathrm{~L}^{-1}$, with an analytical frequency of 90 samples $\mathrm{h}^{-1}$. Quintino et al. ${ }^{18}$ determined ASA, after its hydrolysis to salicylate in a $0.10 \mathrm{~mol} \mathrm{~L}^{-1}$ $\mathrm{NaOH}$ solution, by using amperometric detection with a copper electrode in a BIA system. This method presented a linear analytical curve in the range $1.0 \times 10^{-6} \mathrm{~mol} \mathrm{~L}^{-1}$ to $1.0 \times 10^{-3} \mathrm{~mol} \mathrm{~L}^{-1}$, using an injected volume of $100 \mu \mathrm{L}$, with a detection limit of $0.48 \mu \mathrm{mol} \mathrm{\textrm {L } ^ { - 1 }}$. Majdi et al. ${ }^{19}$ developed a nickel hydroxide-modified nickel electrode for determination of ASA in alkaline medium. The analytical curve was linear in the ASA concentration range $4.0 \times 10^{-4}$ to $6.0 \times 10^{-3} \mathrm{~mol} \mathrm{~L}^{-1}$, with a detection limit of $48 \mu \mathrm{mol} \mathrm{L}{ }^{-1}$. Supalkova et al. ${ }^{20}$ used square-wave voltammetry (SWV), with either a carbon paste electrode (CPE) or a graphite pencil as working electrode, to indirectly determine ASA, after its hydrolysis to SA and AA at $90{ }^{\circ} \mathrm{C}$ and $\mathrm{pH} 12$ for $60 \mathrm{~min}$, since ASA does not yield any SWV signal on the surface of CPE or graphite pencil. Torriero et al. ${ }^{21}$ employed a glassy-carbon electrode for SA determination in solid pharmaceutical formulations containing ASA as majority compound and observed that the SA in a Britton-Robinson buffer solution ( $\mathrm{pH} 2.37$ ) yields a single irreversible oxidation wave, at $1.088 \mathrm{~V} v s$. $\mathrm{Ag} / \mathrm{AgCl}$. This method presented a linear analytical curve over the SA concentration range $1 \mu \mathrm{g} \mathrm{mL}^{-1}$ to $60 \mu \mathrm{g} \mathrm{mL}^{-1}$, with a detection limit of $0.09 \mu \mathrm{g} \mathrm{mL}^{-1}$, but it requires cold methanol for extraction of ASA from the samples. Despite the very good results found by these authors, as discussed above, their methods are time-consuming because of the need of a previous alkaline hydrolysis of ASA.

SWV is one of the most sensitive and direct analytical techniques, which has been used for the sensitive and quick determination of a wide range of organic molecules, with a low nonfaradaic current and high sensitivity. In most instances this method presents further advantages: no need for sample pretreatment and less sensitivity to matrix effects than other analytical techniques. ${ }^{22-25}$

Natural diamond is an insulator, but when doped with boron this material presents either semiconducting or semimetallic electronic properties, depending on the doping level. Recently, thin films of boron-doped diamond (BDD) emerged as a unique electrode material for several electrochemical applications, especially in electroanalysis. ${ }^{26-33}$ BDD electrodes possess very attractive properties, which are significantly different from those of other conventional electrodes, e.g. glassy-carbon or platinum electrodes. BDD, besides being corrosion stable in very aggressive media, presents a very low and stable background current, an extreme electrochemical stability in both alkaline and acidic media, a high response sensitivity, and a very wide working potential window, which can be larger than $3.5 \mathrm{~V}^{34-37}$

In this paper the development and optimization of a square-wave (SW) voltammetric method exploiting the unique properties of BDD for the direct determination of ASA in pharmaceutical formulations for adults and children is described. This method is an attractive alternative because of its high sensitivity, relatively low cost, simplicity, and speed. 


\section{Experimental}

\section{Reagents and solutions}

All reagents were of analytical grade, and the solutions were prepared using water (> $18 \mathrm{M} \Omega \mathrm{cm}$ ) from a Milli-Q (Millipore $^{\circledR}$ ) purification system.

ASA was obtained from Sigma and sulfuric acid from Merck; potassium nitrate, sodium hydroxide, boric acid, acetic acid, and orthophosforic acid were obtained from Synth. The pharmaceutical ASA samples were purchased from a local drugstore. Potassium nitrate, sodium hydroxide, sulfuric acid, and Britton-Robinson buffer $\left(0.04 \mathrm{~mol} \mathrm{~L}^{-1}\right.$ in acetic, orthophosforic, and boric acids adjusted to the pH 9.01 with $0.2 \mathrm{~mol} \mathrm{~L}^{-1}$ sodium hydroxide) solutions were prepared for supporting-electrolyte studies.

A standard $0.01 \mathrm{~mol} \mathrm{~L}^{-1}$ ASA solution was prepared before use in a $0.01 \mathrm{~mol} \mathrm{~L}^{-1} \mathrm{H}_{2} \mathrm{SO}_{4}$ solution and sonicated for $10 \mathrm{~min}$ to achieve complete dissolution. Appropriate dilutions were made from this solution.

\section{Construction of the analytical curve}

After optimizing the experimental parameters for the proposed method, the analytical curve was constructed by addition of aliquots of a standard solution of $1.0 \times 10^{-3} \mathrm{~mol} \mathrm{~L}^{-1}$ ASA in $0.01 \mathrm{~mol} \mathrm{~L}^{-1} \mathrm{H}_{2} \mathrm{SO}_{4}$ into the measurement cell containing a $0.01 \mathrm{~mol} \mathrm{~L}^{-1} \mathrm{H}_{2} \mathrm{SO}_{4}$ solution. $\mathrm{SW}$ voltammograms were obtained after each aliquot addition.

\section{Analysis of pharmaceutical samples}

To prepare solutions of the ASA commercial samples, a representative number of ASA tablets (5 or 10) of each pharmaceutical sample were reduced to a homogeneous fine powder in a mortar. Then, an accurate mass of the powder was transferred to a $10 \mathrm{~mL}$ volumetric flask and the volume was made up with $0.01 \mathrm{~mol} \mathrm{~L}^{-1} \mathrm{H}_{2} \mathrm{SO}_{4}$; the resulting solution was sonicated for $10 \mathrm{~min}$. Non-dissolved solids were filtered using a filter paper; after, $60 \mu \mathrm{L}$ of each sample solution were directly transferred to the electrochemical cell containing $10 \mathrm{~mL}$ of $0.01 \mathrm{~mol} \mathrm{~L}^{-1} \mathrm{H}_{2} \mathrm{SO}_{4}$ and the SW voltammograms were obtained. The ASA concentration in each sample solution was determined by interpolation in an analytical curve previously obtained with reference (standard) solutions.

\section{Reference method}

In order to compare the results obtained with the proposed SWV method, a back-titration method of the British
Pharmacopoeia ${ }^{6}$ was employed with a minor modification. ${ }^{10}$ An accurate representative amount of ASA powder from each sample was treated with $25 \mathrm{~mL}$ of a $0.492 \mathrm{~mol} \mathrm{~L}^{-1}$ $\mathrm{NaOH}$ solution and heated in a domestic microwave oven to ensure the complete ASA hydrolysis, avoiding boiling the solution. After cooling the solution to $25^{\circ} \mathrm{C}$, excess $\mathrm{NaOH}$ was titrated with a standardized $0.508 \mathrm{~mol} \mathrm{~L}^{-1} \mathrm{HCl}$ solution, using phenolphthalein as indicator.

\section{Apparatus}

Electrochemical experiments were conducted in a single-compartment glass cell provided with three electrodes. An Ag/AgCl (3.0 mol L-1 $\mathrm{KCl})$ electrode was used as reference and the counter electrode was a Pt wire. The working electrode $\left(0.33 \mathrm{~cm}^{2}\right.$ exposed area) was a boron-doped (8000 ppm) diamond film on a silicon wafer from Centre Suisse de Electronique et de Microtechnique SA (CSEM), Neuchatêl, Switzerland. ${ }^{37}$ Details on the preparation of these diamond films were reported by Gandini et al. ${ }^{38}$ Prior to the experiments, the BDD electrode was firstly cleaned with ethanol; then it was electrochemically pre-treated in a $0.5 \mathrm{~mol} \mathrm{~L}^{-1} \mathrm{H}_{2} \mathrm{SO}_{4}$ solution by applying $1.0 \mathrm{~A}$ for $60 \mathrm{~s}$, followed by $-1.0 \mathrm{~A}$ for $120 \mathrm{~s}$; this way, the BDD surface was made predominantly H-terminated. ${ }^{29}$ The voltammetric measurements were carried out using an EGG-PAR potentiostat/galvanostat, model 273A. The $\mathrm{pH}$ was measured at $25 \pm 1{ }^{\circ} \mathrm{C}$ using an Orion pH-meter, Expandable Ion Analyser, model EA-940, employing a combined glass electrode with an $\mathrm{Ag} / \mathrm{AgCl}\left(3.0 \mathrm{~mol} \mathrm{~L}^{-1} \mathrm{KCl}\right)$ external reference electrode. The OriginPro 6.0 software was used for the data treatment.

\section{Results and Discussion}

The development of the here reported electroanalytical procedure involved a systematic study for the optimization of the experimental parameters that affect the SW-voltammetric response: supporting-electrolyte concentration and SW frequency $(f)$, pulse amplitude $(a)$, and scan increment $\left(\Delta E_{S}\right)$.

Firstly, preliminary cyclic-voltammetric $\left(50 \mathrm{mV} \mathrm{s}^{-1}\right)$ studies on the electrochemical oxidation of ASA $\left(1.0 \times 10^{-3} \mathrm{~mol} \mathrm{~L}^{-1}\right)$ at the BDD electrode employing different supporting electrolytes were performed: $(a)$ Britton-Robinson buffer ( $\mathrm{pH} 9.01$ ); (b) $0.5 \mathrm{~mol} \mathrm{~L}^{-1} \mathrm{KNO}_{3}$; (c) $0.01 \mathrm{~mol} \mathrm{~L}^{-1} \mathrm{H}_{2} \mathrm{SO}_{4}$; (d) $0.1 \mathrm{~mol} \mathrm{~L}^{-1} \mathrm{NaOH}$ (see Figure 2). Since the response in the $\mathrm{H}_{2} \mathrm{SO}_{4}$ solution is characterized by a well-defined oxidation peak (see Figure 2B), this solution was chosen as the suitable medium (supporting electrolyte) for further experiments. 

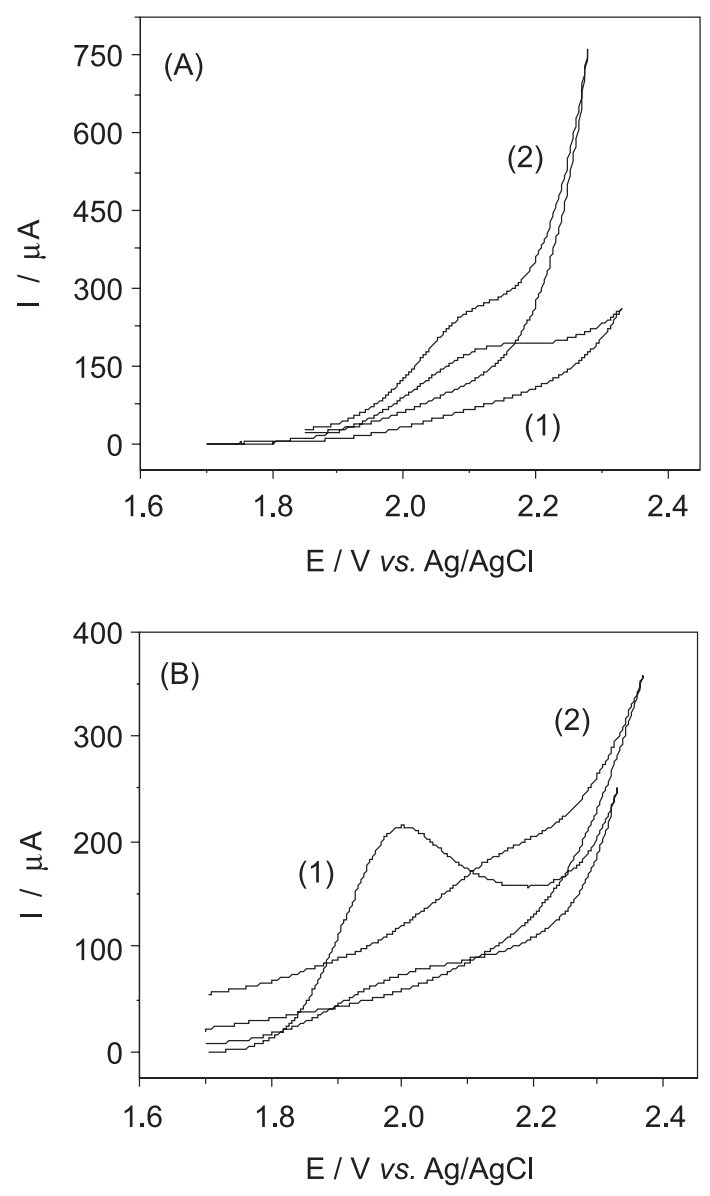

Figure 2. Cyclic voltammograms $\left(50 \mathrm{mV} \mathrm{s}^{-1}\right)$ obtained using the BDD electrode as working electrode for $1.0 \times 10^{-3} \mathrm{~mol} \mathrm{~L}^{-1} \mathrm{ASA}$ in different supporting electrolytes; (A): (1) Britton-Robinson buffer (pH 9.01); (2) $0.5 \mathrm{~mol} \mathrm{~L}^{-1} \mathrm{KNO}_{3}$; (B): (1) $0.01 \mathrm{~mol} \mathrm{~L}^{-1} \mathrm{H}_{2} \mathrm{SO}_{4}$; (2) $0.1 \mathrm{~mol} \mathrm{~L}^{-1} \mathrm{NaOH}$.

The effect of the $\mathrm{H}_{2} \mathrm{SO}_{4}$ concentration was also investigated from $1.0 \times 10^{-3} \mathrm{~mol} \mathrm{~L}^{-1}$ to $0.5 \mathrm{~mol} \mathrm{~L}^{-1}$, for $1.0 \times 10^{-3} \mathrm{~mol} \mathrm{~L}^{-1}$ ASA. The obtained results showed that the peak current presents a maximum value for $0.01 \mathrm{~mol} \mathrm{~L}^{-1}$ $\mathrm{H}_{2} \mathrm{SO}_{4}$. Thus, the subsequent ASA analytical determinations were carried out using a $0.01 \mathrm{~mol} \mathrm{~L}^{-1} \mathrm{H}_{2} \mathrm{SO}_{4}$ solution as the supporting electrolyte. Under these conditions, the method is selective for ASA, avoiding its hydrolysis because in the $\mathrm{pH}$ range 2 to 3 the ASA hydrolysis kinetics is very slow. ${ }^{5,20,21}$ To confirm this, the stability of the $1.0 \times 10^{-3} \mathrm{~mol} \mathrm{~L}^{-1} \mathrm{ASA}$ stock solution in $0.01 \mathrm{~mol} \mathrm{~L}^{-1} \mathrm{H}_{2} \mathrm{SO}_{4}$ was studied during a $8 \mathrm{~h}$ period at $25^{\circ} \mathrm{C}$ by monitoring the ASA concentration by cyclic voltammetry. The obtained results presented no significant differences within a relative standard deviation of $1.6 \%$, indicating that the ASA hydrolysis was negligible.

The SW voltammograms obtained using the BDD electrode presented features similar to those initially obtained by cyclic voltammetry. A single irreversible oxidation peak at $1.97 \mathrm{~V}$ vs. $\mathrm{Ag} / \mathrm{AgCl}\left(3.0 \mathrm{~mol} \mathrm{~L}^{-1} \mathrm{KCl}\right)$ was obtained

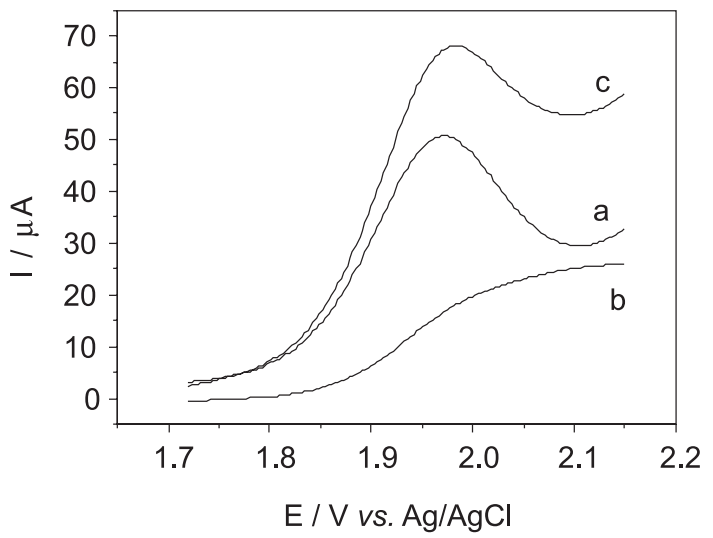

Figure 3. SW-voltammetric response of the BDD electrode for a $1.05 \times$ $10^{-4} \mathrm{~mol} \mathrm{~L}^{-1}$ ASA solution (in $0.01 \mathrm{~mol} \mathrm{~L}^{-1} \mathrm{H}_{2} \mathrm{SO}_{4} ; a=40 \mathrm{mV}, \Delta E_{S}=3 \mathrm{mV}$, $f=50 \mathrm{~Hz}$ ): (a) direct current; (b) reverse current; (c) total current.

using both electroanalytical techniques, confirming the irreversible nature of the observed ASA electrooxidation in the potential window investigated. Figure 3 presents the SWvoltammetric results obtained using the BDD electrode for a $1.05 \times 10^{-4} \mathrm{~mol} \mathrm{~L}^{-1} \mathrm{ASA}$ solution, at the conditions described in the legend of this figure.

\section{Optimization of the experimental parameters}

The SW frequency $(f)$ is of extreme importance in SWV since it determines the intensity of the analytical signal and, consequently, the sensitivity of the technique. In this study, the peak current was found to be a linear function of $f$, with a peak potential displacement towards more positive values. According to accepted SWV theory, ${ }^{39}$ this behavior corresponds to a totally irreversible system controlled by adsorption of the species on the electrode surface. A baseline increase was also observed when $f$ was increased. Therefore, for the subsequent analytical applications, $f$ was fixed at $50 \mathrm{~Hz}$ because a stable baseline and a good voltammogram definition were thus obtained. The SW pulse amplitude $(a)$ is another parameter that strongly influences the values of the peak current in SWV, hence also determining the sensitivity of this technique. The obtained results showed that the peak current varies linearly for values of $a$ up to $10 \mathrm{mV}$ and reaches a plateau for $a \geq 40 \mathrm{mV}$. Therefore, $a$ was set at $40 \mathrm{mV}$ for the subsequent analytical application.

The effective rate of potential variation in SWV is the product between $f$ and $\Delta E_{\mathrm{S}}$. In addition, the latter parameter also increases the analytical signal and sensitivity of this technique. However, a widening of the peak may occur for large values of $\Delta E_{\mathrm{s}}$, thus diminishing the analysis resolution. ${ }^{22,23}$ In this study, the peak current increased significantly for $\Delta E_{\mathrm{S}}$ values up to about $4 \mathrm{mV}$, then leveling 
off. Hence, for the analytical applications, $\Delta E_{\mathrm{S}}$ was set at $3 \mathrm{mV}$.

\section{Analytical Curve for ASA}

Figure 4 shows the SW voltammograms obtained for ASA reference solutions at different concentrations (from 0 to $1.05 \times 10^{-4} \mathrm{~mol} \mathrm{~L}^{-1}$ ) in $0.01 \mathrm{~mol} \mathrm{~L}^{-1} \mathrm{H}_{2} \mathrm{SO}_{4}$, after optimization of the experimental parameters (for their values, see legend of Figure 4). The insert in Figure 4 corresponds to the analytical curve obtained, whose corresponding regression equation (correlation coefficient of 0.9995$)$ is:

$$
I_{\mathrm{ap}} / \mu \mathrm{A}=0.488+4.12 \times 10^{5}\left[c /\left(\mathrm{mol} \mathrm{L}^{-1}\right)\right]
$$

where $I_{\text {ap }}$ is the anodic peak current and $c$ the concentration of acetylsalicylic acid. The calculated value of the detection limit (three times the standard deviation of the blank solution/ slope of the analytical curve) was $2.0 \times 10^{-6} \mathrm{~mol} \mathrm{~L}^{-1}$. The repeatability was determined by successive measurements of $4.5 \times 10^{-5} \mathrm{~mol} \mathrm{~L}^{-1}$ ASA solutions $(\mathrm{n}=10)$, with a relative standard deviation of $1.4 \%$.

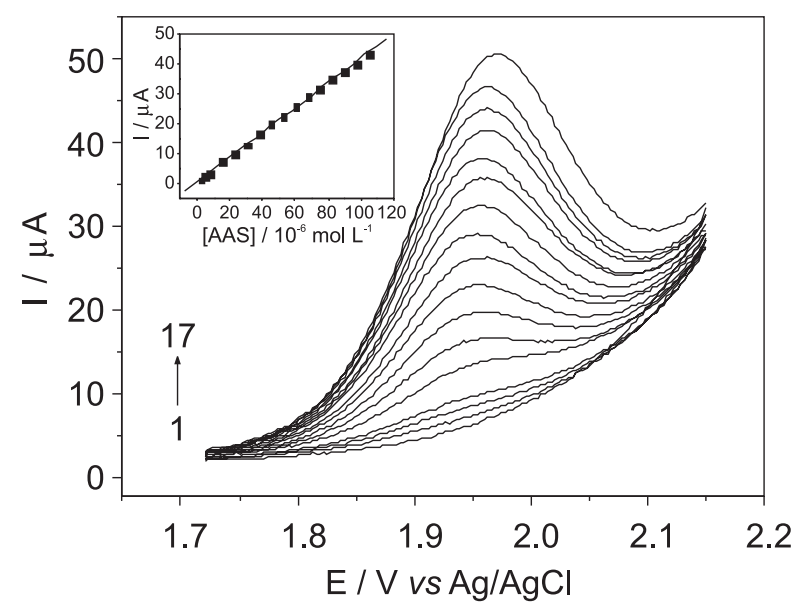

Figure 4. SW-voltammetric response (direct current) of the BDD electrode for different ASA concentrations in $0.01 \mathrm{~mol} \mathrm{~L}^{-1} \mathrm{H}_{2} \mathrm{SO}_{4}$ : (1) 0 ; (2) $2.50 \times 10^{-6}$; (3) $5.00 \times 10^{-6}$; (4) $7.50 \times 10^{-6}$; (5) $1.50 \times 10^{-5}$; (6) $2.25 \times 10^{-5}$; (7) $3.00 \times 10^{-5}$; (8) $3.75 \times 10^{-5}$; (9) $4.50 \times 10^{-5}$; (10) $5.25 \times 10^{-5}$; (11) $6.00 \times 10^{-5}$; (12) $6.75 \times 10^{-5}$; (13) $7.50 \times 10^{-5}$; (14) $8.25 \times 10^{-5}$; (15) $9.00 \times 10^{-5}$; (16) $9.75 \times 10^{-5}$; (17) $1.05 \times 10^{-4} \mathrm{~mol} \mathrm{~L}^{-1}$. Insert: Analytical curve for the ASA oxidation process.

\section{Possible interferents}

The selectivity of the proposed method was evaluated by the concomitant addition of possible interferents (saccharin, manithol, sucrose, fructose, glucose, starch, yellow sunset ( $\mathrm{Cl} 15985)$, and erythrosin red $(\mathrm{Cl} 45430)$ ) to $5.0 \times 10^{-5} \mathrm{~mol} \mathrm{~L}^{-1} \mathrm{ASA}$ solutions at the concentration ratios 1:1, 1:10, and 10:1. The responses were compared with that obtained using only the ASA standard solution. The obtained responses showed that these compounds do not interfere with the determination of ASA at the used working conditions. Only starch, in high concentration, promoted an increase and a shift of the ASA oxidation peak to more positive potential values. Nevertheless, in the analyzed samples the starch concentration is lower than those studied in this work, thus not interfering in the determination of ASA, as it was confirmed with the addition and recovery study.

\section{Addition and recovery study}

An addition and recovery study was performed by adding known amounts of standard solutions to a given sample followed by analysis using the proposed SWV method. The results presented in Table 1 show that the ASA recoveries range from $93.3 \%$ to $107 \%$ for the commercial tablets, indicating absence of a matrix effect.

Table 1. Addition and recovery of acetylsalicylic acid (ASA) from pharmaceutical products by the proposed SWV method using a borondoped diamond electrode

\begin{tabular}{lccc}
\hline \multirow{2}{*}{ Samples } & \multicolumn{2}{c}{ ASA $/\left(10^{-5} \mathrm{~mol} \mathrm{~L}^{-1}\right)$} & Recovery $/(\%)$ \\
\hline Adult ASA & Added & Found & \\
\hline \multirow{2}{*}{ A } & & & \\
& 1.50 & 1.40 & 93.3 \\
& 3.00 & 2.99 & 99.7 \\
B & 4.50 & 4.53 & 101 \\
\hline Children ASA & 1.50 & 1.53 & 102 \\
\hline \multirow{3}{*}{ A } & 3.00 & 3.17 & 106 \\
& 4.50 & 4.80 & 107 \\
\hline \multirow{2}{*}{ B } & 1.50 & & 101 \\
& 3.00 & 2.99 & 99.7 \\
& 4.50 & 4.59 & 102 \\
\hline
\end{tabular}

average of 3 measurements.

\section{Analytical application}

Table 2 presents the ASA amounts determined in several commercial ASA tablets employing the proposed SWV method and a standard method of the British Pharmacopoeia. ${ }^{6}$ Three determinations were done for each sample, and the standard deviations were calculated. The 
Table 2. Determination of acetylsalicylic acid (ASA) in pharmaceutical products by a British Pharmacopoeia (reference) and the proposed SWV methods using a boron-doped diamond electrode

\begin{tabular}{|c|c|c|c|c|c|}
\hline \multirow{2}{*}{ Samples } & \multicolumn{3}{|c|}{ ASA tablet / mg } & \multicolumn{2}{|c|}{ Relative error / (\%) } \\
\hline & Label value & Reference method $^{\mathrm{a}}$ & SWV method ${ }^{a}$ & $\mathrm{RE}_{1}^{\mathrm{b}}$ & $\mathrm{RE}_{2}^{\mathrm{c}}$ \\
\hline \multicolumn{6}{|c|}{ Adult ASA tablets } \\
\hline A & 500 & $498 \pm 3$ & $498 \pm 1$ & -0.4 & 0 \\
\hline B & 500 & $501 \pm 1$ & $503 \pm 2$ & 0.6 & 0.4 \\
\hline \multicolumn{6}{|c|}{ Children ASA tablets } \\
\hline A & 100 & $99 \pm 1$ & $97 \pm 1$ & -3 & -2 \\
\hline B & 85 & $85 \pm 1$ & $86 \pm 1$ & 1 & 1 \\
\hline
\end{tabular}

${ }^{a}$ Average of 3 measurements. ${ }^{b} \mathrm{RE}_{1}=100 \times$ (voltammetric value - label value) / label value. ${ }^{\mathrm{c}} \mathrm{RE}_{2}=100 \times($ voltammetric value - reference method) / reference method.

amount of the ASA in each sample solution was determined by interpolation in an analytical curve previously obtained with reference (standard) solutions. The paired $t$-test ${ }^{40}$ was applied to the results obtained using both methods; the fact that the calculated $t$ value (2.644) is smaller that the critical value (3.182, $\alpha=0.05)$ indicates that there is no difference (at a confidence level of $95 \%$ ) between the obtained results.

\section{Conclusions}

The present study shows that SWV using a BDD electrode can be used to determine the ASA content in several pharmaceutical products, with ASA dissolved in a $0.01 \mathrm{~mol} \mathrm{~L}^{-1} \mathrm{H}_{2} \mathrm{SO}_{4}$ solution. Optimization of the experimental parameters yielded a detection limit for ASA of $2.0 \mu \mathrm{mol} \mathrm{L}^{-1}$ and a relative standard deviation smaller than $1.4 \%$ for $45 \mu \mathrm{mol} \mathrm{L}^{-1}$ ASA solutions $(\mathrm{n}=10)$. Addition-recovery tests were satisfactory, with values similar to those obtained using an official method of the British Pharmacopoeia ${ }^{6}$ and to the label values. In addition, the reported results demonstrate that the combination of SWV with a BDD electrode is a feasible alternative for the analytical determination of ASA in commercial adult and children tablets without previous hydrolysis of the analyte as required by other methods ${ }^{6,7,10,11,15-20}$ or the necessity of expensive apparatus along with time-consuming sample preparations..$^{13,14}$

\section{Acknowledgments}

The authors thank CAPES (Coordenação de Aperfeiçoamento de Pessoal de Nível Superior), CNPq (Conselho Nacional de Desenvolvimento Científico e Tecnológico), and FAPESP (Fundação de Amparo à Pesquisa do Estado de São Paulo) for financial support and scholarships; O.F.F. is also grateful to CAPES for a post-doctoral scholarship (proc. 4383-07/9).

\section{References}

1. Hammerschmidt, D. E.; J. Lab. Clin. Med. 1998, 132, 556.

2. Sneader W.; British Med. J. 2000, 321, 1591.

3. Thiessen, J. J. In Acetylsalicylic Acid: New Uses for an Old Drug; Barnett, H. J. M.; Hirsh, J.; Mustard, J. F., eds., Raven Press: New York, 1992, pp. 49-61.

4. Elwood, P. C.; Clin. Med. 2001, 1, 132.

5. Connors, K. A.; Amidon, G. L.; Kennon, L.; Chemical Stability of Pharmaceuticals, Wiley: New York, 1979, p. 151.

6. British Pharmacopoeia, HMSO: London, 1980, p. 733.

7. Trinder, P.; Biochem. J. 1954, 57, 301.

8. Matias, F. A. A.; Vila, M. M. D. C.; Tubino, M.; J. Braz. Chem. Soc. 2004, 15, 327.

9. Verma, K. K.; Jain, A.; Anal. Chem. 1986, 58, 821.

10. Pereira. A. V.; Aniceto, C.; Fatibello-Filho, O.; Analyst 1998, 123, 1011.

11. Ruiz-Medina, A.; Córdoba, M. L. F.; Ortega-Barrales, P.; Molina-Díaz, A.; Int. J. Pharm. 2001, 216, 95.

12. Miles, C. I.; Schenk, G. H.; Anal. Chem. 1970, 42, 656.

13. Gandhimathi, M.; Ravi, T. K.; Abraham, A.; Thomas, R.; J. Pharm. Biomed. Anal. 2003, 32, 1145.

14. DiPietra, A. M.; Gatti, R.; Andrisano, V.; Cavrini, V.; J. Chromatogr., A 1996, 729, 355.

15. Ferreira, V. J. F.; Cavalheiro, A. C. V.; Fagnani, E.; de Moraes, M.; Pezza, L.; Melios, C. B.; Anal. Sci. 1999, 15, 249.

16. Kubota, L. T.; Fernandes, J. C. B.; Rover Jr, L.; Oliveira-Neto, G.; Talanta 1999, 50, 661.

17. Fernandes, J. C. B.; Garcia, C. A. B.; Gandin, L. A.; Oliveira Neto, G.; Godinho, O. E. S.; J. Braz. Chem. Soc. 1998, 9, 249.

18. Quintino, M. S. M.; Corbo, D.; Bertotti, M.; Angnes, L.; Talanta 2002, 58, 943.

19. Majdi, S.; Jabbari, A.; Heli, H.; J. Solid State Electrochem. 2007, 11, 601.

20. Supalkova, V.; Petrek, J.; Havel, L.; Krizkova, S.; Petrlova, J.; Adam, V.; Potesil, D.; Babula, P.; Beklova, M.; Horna, A.; Kizek, R.; Sensors 2006, 6, 1483. 
21. Torriero, A. A. J.; Luco, J. M.; Sereno, L.; Raba, J.; Talanta 2004, 62, 247.

22. Codognoto, L.; Machado, S. A. S.; Avaca, L. A.; Diamond Relat. Mater. 2002, 11, 1670.

23. Souza D.; Machado, S. A. S.; Avaca, L. A.; Quim. Nova 2003, 26,81 .

24. Pedrosa, V. A.; Codognoto, L.; Avaca, L. A.; Quim. Nova 2003, $26,844$.

25. Osteryoung, J.; Osteryoung, R.; Anal. Chem. 1985, 57, 101A.

26. Pleskov, Y. V.; J. Anal. Chem. 2000, 55, 1045.

27. Hupert, M.; Muck, A.; Wang J.; Stotter, J.; Cvakova, Z.; Haymond, S.; Show, Y.; Swain, G. M.; Diamond Relat. Mater. 2003, 12, 1940.

28. Swain, G. M. In Electroanalytical Chemistry; Bard, A. J.; Rubinstein, I., eds.; Marcel Dekker: New York, 2004, Vol. 22, p.182.

29. Suffredini, H. B.; Pedrosa, V. A.; Codognoto, L.; Machado, S. A. S; Rocha-Filho, R. C.; Avaca, L. A.; Electrochim. Acta 2004, 49, 4021.

30. Banks, C. E.; Compton, R. G.; Analyst 2006, 131, 15.

31. Medeiros, R. A.; Carvalho, A. E.; Rocha-Filho, R. C.; FatibelloFilho, O.; Anal. Lett. 2007, 40, 3195.

32. Medeiros, R. A.; Carvalho, A. E.; Rocha-Filho, R. C.; FatibelloFilho, O.; Talanta 2008, 76, 685.
33. Medeiros, R. A.; Carvalho, A. E.; Rocha-Filho, R. C.; FatibelloFilho, O.; Quim. Nova 2008, 31, 1405.

34. Pleskov, Y. V.; Russ. J. Electrochem. 2002, 38, 1275.

35. Zhang, Y.; Yoshihara, S.; J. Electroanal. Chem. 2004, 573, 327.

36. Compton, R. G.; Foord, J. S.; Marken, F.; Electroanalysis 2003, 15, 1349.

37. Salazar-Banda, G. R.; Andrade, L. S.; Nascente, P. A. P.; Pizani, P. S.; Rocha-Filho, R. C.; Avaca, L. A.; Electrochim. Acta 2006, 51, 4612 .

38. Gandini, D.; Michaud, P.; Duo, I.; Mache, E.; Haenni, W.; Perret, A.; Conminellis, C.; New Diamond Front. Carbon Technol. 1999, 9, 303.

39. Lovric, M.; Komorsky, S.; Murray, R. W.; Electrochim. Acta 1988, 33, 739.

40. Anderson, R. L.; Practical Statistics for Analytical Chemists, Van Nostrand Reinhold Company: New York, 1987.

Received: July 28, 2008

Web Release Date: January 22, 2009

FAPESP helped in meeting the publication costs of this article. 